\title{
dossier
}

\section{Un ejemplo de interacción jurídica entre la Iglesia} y la Corona. La participación del arzobispo Toribio Mogrovejo en el proceso de toma de decisión de la Monarquía Hispánica (1580-1606)

\author{
Flavia TUDINI \\ Istituto Italiano per gli Studi Storici (Nápoles, Italia) \\ flavia.tudini@gmail.com
}

Código ORCID: 0000-0002-6342-3997

\section{RESUMEN}

El objetivo del artículo es demostrar la importancia y el papel que desempeñó el arzobispo de Lima Toribio Mogrovejo (1580-1606) en la circulación de la información y en el proceso de toma de decisiones de la Monarquía Hispánica a finales del siglo XVI. Los casos que se considerarán se refieren al gobierno de las doctrinas de indios y a la sustitución del clero regular con el secular en ellas. A través del análisis de los casos de estudio se pretende mostrar la influencia de las observaciones 
y sugerencias enviadas por el arzobispo al rey, en el proceso de toma de decisión de los territorios americanos.

Palabras Clave: Toribio Mogrovejo, Lima, doctrinas de indios, diócesis, Monarquía Hispánica, toma de decisión

An example of juridical interaction between the Church and the Crown. The participation of Archbishop Toribio Mogrovejo in the decision-making process of the Hispanic Monarchy (1580-1606)

\begin{abstract}
The article aims to demonstrate the importance the role of the archbishop of Lima Toribio Mogrovejo (1580-1606) had for the circulation of information and the decision-making process of the Hispanic Monarchy at the end of the 16th century. The article will consider three case studies about the governance of the doctrinas de indios and the substitution of the regular clergy. Through the analysis of the case studies the article demonstrates the influence of the observations and suggestions sent by the archbishop to the king within the decisionmaking process for the American territories.
\end{abstract}

KEYworDs: Toribio Mogrovejo, Lima, doctrinas de indios, diocese, Hispanic Monarchy, decision-making process

\title{
1. Introducción. SABer y gobierno en la América hispánica
}

LAS CARACTERÍSTICAS GEOGRÁFICAS, ANTES QUE las políticas, hicieron de la Monarquía Hispánica un sistema complejo, que tenía aspectos específicos dentro del panorama político de la Europa de los siglos XVI-XVII. En los años treinta del siglo XVII, Juan de Solórzano y Pereira observó cómo la monarquía se extendía desde Europa hasta América, desde los Flandes hasta los territorios portugueses en las Indias Orientales (Solórzano Pereira, 2001, I, pp. 588-590), dominando «las cuatros partes el mundo» (Gruzinski, 2006, 2010). Las características plurales de la monarquía, la discon- 
tinuidad de sus dominios, la distancia de algunos de ellos de la Corte de Madrid y la dificultad de los viajes, imposibilitaban la presencia física del rey en sus diferentes reinos. Se convirtió así en un soberano lejano, cuya ausencia fue compensada por un rico aparato simbólico y un estilo de gobierno que permitía a sus súbditos vincularse a la Corona y familiarizarse con la imagen del rey (Hernando Sánchez, 1996; Calvo, 2000, pp. 427-483).

El problema de las distancias geográficas en la organización y gestión de las entidades políticas nacidas como resultado de la conquista de territorios distantes, entre los siglos XVI y XVII, es un tema que la historiografía no ha dejado de tratar y que recientemente ha sido objeto de nuevas interpretaciones. Los estudios han puesto de manifiesto las dificultades del gobierno debido a la distancia y las estrategias desarrolladas para superarlas (Gaudin, 2013; Sellers-García, 2014; González Martínez, 2017). Esto significaba no solo tratar de eliminar en la medida de lo posible las barreras de comunicación entre la Corona y sus lejanos funcionarios, sino que también implicaba enfrentarse a un problema político mucho más relevante. A las dificultades de comunicación siguieron inevitablemente las dificultades para gobernar el territorio. La distancia hizo «ciego» al soberano, que no fue capaz de conocer las necesidades de los territorios ni de actuar con prontitud para asegurar el buen gobierno que garantizaba la lealtad de sus súbditos. Esta situación era particularmente importante para los territorios americanos, sobre todo en relación con las tareas administrativas y gubernamentales llevadas a cabo por el Consejo de Indias (Barrios Pintado, 2015), que debería asistir al soberano en los asuntos americanos y que no estaba preparado para la realidad que tenía que gobernar y administrar. En 1569, en las ordenanzas que siguieron a su visita al Consejo de Indias, Juan de Ovando subrayó las dificultades de gobernar estos territorios tan lejanos y amplios sin el conocimiento adecuado por parte del soberano y de sus consejeros. Estos deberían ser expertos conocedores de la realidad, sobre las que se les pidió que ex- 
presaran sus opiniones y tomaran decisiones legalmente vinculantes. Se presentaba así un aspecto fundamental para el gobierno del territorio y que era capaz de superar las limitaciones de la distancia: la «entera noticia», o sea, la descripción verdadera y precisa de la realidad considerada. Se creó por tanto un vínculo entre conocimiento y gobierno de los territorios (Brendecke, 2016, pp. 21-33). Sobre este tema, el historiador Arndt Brendecke ha observado cómo la relación entre el uso del conocimiento y el dominio colonial se basaba en dos supuestos fundamentales, que estaban estrechamente relacionados. Por un lado, el gobierno colonial necesitaba producir descripciones fiables de realidades distantes, a través de funcionarios reales en contacto con Madrid. Por otra parte, los elementos cognitivos estaban vinculados a las prácticas de dominación y administración: el conocimiento del territorio era necesario para ejercer una acción gubernamental eficaz (Brendecke, 2016, p. 19; Navarro Bonilla, 2006, pp. 133-158). El soberano estaba, sin embargo, sujeto a limitaciones humanas y, por lo tanto, era incapaz de saber todo sin el apoyo de un aparato de funcionarios y agentes que le mantenían constantemente informado (Brendecke, 2016, pp. 86-87).

Durante el reinado de Felipe II (1556-1598) se fortaleció la relación entre la observación de los territorios, el proceso de toma de decisión y la elaboración de las normas necesarias para el gobierno de los virreinatos americanos. Esto fue particularmente importante sobre todo en relación con las características «casuísticas» del Derecho indiano (Sánchez Bella, De la Hera y Díaz Rementería, 1992; Tau Anzoátegui, 1992, 1997; Duve y Pihlajamäki, 2015), que estimuló la circulación de información, haciendo obligatorio el envío de informes a la Corona. La actividad normativa indiana se orientó a elaborar normas que respondieran a las necesidades y situaciones contingentes que se observaban en el territorio, de manera que el conocimiento de las condiciones y costumbres particulares, tanto de los nativos como de los españoles que vivían en América, pudiera apoyar las acciones de gobierno, haciéndolas lo más cercanas a la 
realidad del territorio. Esto podría hacer que la acción del gobierno sea más efectiva, haciéndola lo más adherente posible a la realidad del territorio. En consecuencia, la elaboración de normas se desarrolló paralelamente a los diversos memoriales, informes, peticiones y súplicas enviados al rey y al Consejo de Indias (Masters, 2018), que informaron de las necesidades a remediar, reflejando la variada configuración cultural, social o económica de cada reino y provincia.

La conexión entre el conocimiento adquirido a través de la observación del territorio, la elaboración de normas y el gobierno de los territorios fue también una característica del gobierno eclesiástico. Las visitas pastorales, de hecho, permitieron a los obispos obtener un conocimiento directo de la realidad diocesana, que luego se utilizaría en la redacción de los decretos de los concilios provinciales. Esto surgió en particular durante la celebración del III Concilio de México (Moutin, 2016) y del III Concilio de Lima (1583) (Tineo, 1990; Saranyana, 1999; Martínez Ferrer, 2017).

Tau Anzoátegui ha observado que los decretos emitidos por los Concilios de México y Lima en el siglo XVI, así como los sínodos diocesanos, constituyeron la base de un Derecho canónico particular, desarrollado fuera del poder centralizado de la Iglesia de Roma (Tau Anzoátegui, 2016, p. 27). Más recientemente, Jorge Traslosheros ha recordado cómo, al igual que la legislación civil, el sistema jurídico-canónico se adaptó también a la nueva realidad americana hasta obtener algunas características distintivas, siendo después definido como «Derecho canónico indiano» (Traslosheros, 2014; Albani, Danwerth y Duve, 2019; Terráneo, 2020).

En este complejo panorama es particularmente interesante la figura del arzobispo de Lima Toribio Mogrovejo (1580-1606) (Levillier, 1920; Rodríguez Valencia, 1958), que realizó personalmente tres largas visitas pastorales, superando considerables distancias y numerosas dificultades (Benito, 2006). A través de una densa correspondencia redactada «andando visitando», el arzobispo informó al soberano constantemente y en detalle sobre el estado de la dióce- 
sis. Sin embargo, lo que el arzobispo escribió no tenía un propósito puramente informativo, Mogrovejo dio a conocer la situación al rey para que este pudiera intervenir enviando reales cédulas para remediar las necesidades, conciliar los conflictos y regular las situaciones más controvertidas.

Dentro de las más variadas solicitudes relativas a las doctrinas de indios, a la presencia de los regulares en la diócesis o a las fundaciones religiosas, surgieron también cuestiones relacionadas de manera particular con el gobierno espiritual de la diócesis y que formaban parte de los derechos de patronato concedidos por la Santa Sede a la Corona desde la primera década del siglo XVI. En este caso, el arzobispo pidió la mediación del rey para que se hicieran peticiones y solicitudes a la Santa Sede, en relación tanto con cuestiones relativas al gobierno de la diócesis como con aspectos que involucraban la vida de la Iglesia americana en general.

Por lo tanto, gracias a esto, el arzobispo pudo presentar la sociedad americana y sus dinámicas al rey desde un punto de vista diferente al del virrey y de los funcionarios reales presentes en el territorio. Como máxima autoridad eclesiástica del virreinato del Perú, Mogrovejo poseía una sensibilidad diferente a las cuestiones sociales que se relacionaban con el progreso de la evangelización, y que las autoridades civiles presentaban eminentemente desde la perspectiva del gobierno temporal.

\section{Clero Regular y Clero Secular en las doctrinas de indios}

La presencia de religiosos, con facultades pastorales similares a las de los sacerdotes seculares, dentro de las doctrinas de indios fue inicialmente prevista por una bula papal de Alejandro VI en 1512, que autorizaba a los regulares a hacerse cargo del cuidado de las almas de los nativos hasta que hubiera suficientes sacerdotes en número y capacidad (Bravo Guerreira, 1990). Según las disposiciones 
del Derecho canónico, de hecho, los religiosos no podían poseer beneficios de curas - como las doctrinas - a menos que fueran dispensados por el pontífice. Posteriormente, la bula Omnimoda de Adriano VI, del 5 de mayo de 1522, sancionó la sustitución del clero regular una vez finalizada la primera fase de evangelización y establecida la jerarquía diocesana (García Añoveros, 1990; Cantù, 2007).

La jurisdicción del obispo sobre el clero regular fue objeto de algunos decretos de reforma del Concilio de Trento. En particular, el capítulo 15 de la sesión XXIII reguló la relación entre el obispo y las órdenes religiosas para la posesión de beneficios parroquiales (Morales, 2010). Esta disposición fue revisada por el papa Pío V en la bula Exponi Nobis de 1567, otorgada después de las solicitudes de Felipe II por la Iglesia de América (Pérez Puente, 2009, pp. 7273 , 80-81). El documento establecía que, en los territorios de las Indias Occidentales, las órdenes religiosas podían seguir ejerciendo las facultades parroquiales, quedando también exentas de la visita del obispo y de su jurisdicción. ${ }^{1}$

Las relaciones entre las autoridades civiles y el clero regular en los virreinatos americanos fueron reguladas también por las normas elaboradas en la Junta Magna de 1568 (Ramos Pérez, 1999; Merluzzi, 2007; Pérez Puente, 2009), en las que se intentaba establecer un equilibrio de poder diferente para la Iglesia en las diócesis americanas (Castañeda Delgado y Marchena Fernández, 1992). Debido a la relación conflictiva entre el clero regular y el secular, la Corona intentó reducir progresivamente el poder de las órdenes religiosas y permitió el establecimiento de la Compañía de Jesús (Vargas Ugarte, 1963; Broggio, 2004; Maldavsky, 2012).

Por lo tanto, se puede observar cómo el reinado de Felipe II se caracterizó por una progresiva sustitución de una Iglesia esencialmente misionera, fundada en el ministerio apostólico de las órdenes mendicantes, por una Iglesia fundada en el clero secular, sujeta a

1 Recopilación, lib. 1, tít. 14, 1. 47. 
la jurisdicción del ordinario diocesano (Cantù, 2007, pp. 110-111; Pérez Puente, 2009, p. 72).

A partir de los decretos de la Junta Magna, en 1574 la real cédula del Patronato se ocupó de ciertos aspectos relativos a la concesión de los beneficios eclesiásticos. En particular, trató de la erección de los beneficios de carácter canónico (como las parroquias), fijando los límites que deben asignarse a sus titulares, llamados «curas beneficiados». Además, disponía que las doctrinas de indios estaban sometidas al régimen del Patronato, es decir, que el nombramiento del beneficiario se efectuaba mediante la elección del virrey y la posterior confirmación del obispo. Las doctrinas de indios fueron puestas bajo el régimen del Patronato y la jurisdicción del obispo, asociando la figura del doctrinero a la del párroco (Armas Medina, 1952; Morales, 2010, pp. 55-59).

Por lo tanto, a partir de la segunda mitad del siglo XVI, los obispos americanos aplicaron las normas sancionadas por la Junta Magna y la cédula real del Patronato, prefiriendo al clero secular en las dotaciones de los curas beneficiados (Pérez Puente, 2009; Mazín, 2010 , p. 170). En este complejo panorama, los obispos tendían a preferir a los miembros del clero secular para las doctrinas más alejadas de la sede episcopal; por un lado, por la posibilidad de ejercer un control efectivo y, por otro, por la capacidad de los sacerdotes de expresarse en las principales lenguas de los nativos, tal como lo sancionaron las ordenanzas del virrey Toledo y los concilios provinciales de Lima en 1551, 1567 y 1583 (Vargas Ugarte, 1951; Olmedo Jiménez, 1990; Durston, 2007; Pérez Puente, 2017, pp. 114-115).

Entre los años setentas y ochentas del siglo XVI, las diócesis del Perú vieron un considerable aumento del clero secular debido al incremento de las ordenaciones de sacerdotes criollos (Valpuesta Abajo, 2008, pp. 277-302; Dammert Bellido, 1996, p. 243; García Añoveros, 1990, p. 155), gracias también a la fundación de los seminarios diocesanos promovidos por el virrey Toledo y, después, por el arzobispo Mogrovejo (Lohmann Villena, 1989; Pérez Puente, 2013), 
y a las constantes nuevas llegadas de Europa. Este aumento permitió, por tanto, al virrey Toledo tentar una primera sustitución de los frailes en las parroquias de indios e instruir al clero secular en las lenguas indígenas a partir de 1572 (Pérez Puente, 2017, p. 114). Esta propuesta de sustitución fue también presentada al soberano por los obispos en los años siguientes (Rodríguez Valencia, 1958, II, p. 253).

Por tanto, al final del siglo XVI la geografía eclesiástica del virreinato del Perú resultaba particularmente compleja. En los años ochenta, en la diócesis de Lima los clérigos poseían el 49.2\% de las parroquias y de las doctrinas (llegando al $63.1 \%$ en 1626); en la del Cusco, los clérigos seculares administraban el $83 \%$ de las parroquias y doctrinas del obispado; en las de Las Charcas, La Paz y Chucuito, el $75 \%$; en la de Santiago de Chile, el $73 \%$; y en la de Quito tuvieron alrededor del $58 \%$. Se destacó, por tanto, la profunda diferencia de la provincia eclesiástica del Perú con la de Nueva España, donde en los años setenta del siglo siguiente el clero secular solamente tenía el 26.7 \% de las parroquias y doctrinas (Pérez Puente, 2017, pp. 146147). Esta situación fue influenciada, por un lado, por las ordenanzas y las reducciones ordenadas por el virrey Toledo y, por el otro, por las disposiciones del III Concilio de Lima de 1583.

Con motivo de la celebración del concilio provincial de 1583 , Mogrovejo escribió al rey para informarle sobre el estado de la arquidiócesis, tras la primera visita pastoral en que había tenido la oportunidad de observar la realidad de las doctrinas de los indios. En febrero de 1583, el arzobispo se quejó de la escasez de sacerdotes, cuyo número no permitía satisfacer las numerosas necesidades de las doctrinas:

Después que llegué a esta ciudad e visitado gran parte deste districto por mi persona y lo que he entendido tener necesidad de remedio es proveer y dar doctrina a los yndios por carecer de sacerdotes y tener cada sacerdote en muchas partes muchos lugares de yndios a su cargo y mucha distancia de camino. ${ }^{2}$

2 Carta de Mogrovejo al rey, 25 de febrero de 1583, Archivo General de Indias (en adelante, AGI), Patronato, 248, r. 5. 
Sugirió, por tanto, al rey enviar una súplica al pontífice para que le pudiese conceder una dispensa para la ordinación de sacerdotes «a solo titulo de yndios [y que] [...] estas doctrinas se hiziesen beneficios perpetuos». ${ }^{3}$

Entonces, se puede observar cómo Mogrovejo, para satisfacer las necesidades de su diócesis, buscó a través del rey una solución que no ampliara más las facultades de las órdenes religiosas. Pidió que los sacerdotes fueran ordenados específicamente para las doctrinas, sin que estas fueran concedidas a los religiosos. Además, en la correspondencia entre el arzobispo y la Corona acerca de la celebración del concilio provincial y la actuación práctica de sus decretos, Mogrovejo hizo saber al rey no solo el estado de necesidad en que se encontraban las doctrinas de indios, sino también la conveniencia de permitir que el obispo mantuviera un estrecho control sobre ellas, tanto si estaban dirigidas por el clero secular como por el regular. A finales de septiembre de 1583, una vez clausurado el concilio, el arzobispo pidió al rey que «los religiosos no sean curas sin contentamiento del ordinario y que aya conservadores del Concilio de Trento». ${ }^{4}$ Refiriéndose, por tanto, a la doctrina general del Concilio de Trento y no a la concesión de Pío V, que había derogado algunos aspectos de esta para los religiosos presentes en América, tanto en el virreinato del Perú como en el de Nueva España. Se observa, pues, que las controversias entre los obispos, las órdenes religiosas y los representantes reales en América en relación con las doctrinas de los indios estaban bastante extendidas y, por tanto, la alta jerarquía eclesiástica propuso la «secularización» de las doctrinas, o sea, la substitución total de las órdenes religiosas con el clero secular.

Los decretos de la Junta Magna (1568) y de la real cédula del Patronato (1574) sobre la oportunidad de administrar las parroquias de indios en el marco del real Patronato habían, de hecho, agudiza-

3 Carta de Mogrovejo al rey, 25 de febrero de 1583, AGI, Patronato, 248, r. 5.

4 Carta de los obispos al rey, 30 de septiembre de 1583, AGI, Patronato, 248, r. 8. 
do el conflicto entre las órdenes religiosas y los obispos en las diócesis peruanas y novohispanas. La Corona decidió, entonces, reemplazar el clero regular por el secular en todas las doctrinas, enviando a todas las diócesis de América una real cédula el 6 de diciembre de 1583 (Morales, 2010, p. 61), la primera de las que fueron definidas como las «cedulas de doctrinas» (Pérez Puente, 2009, p. 91).

El texto de la disposición real se basaba en las bulas y breves pontificios de 1512, 1522 y 1567, que habían permitido confiar las parroquias y la administración de los sacramentos al clero regular, dada la escasez de clero secular en la primera fase de la evangelización en el Nuevo Mundo. Aunque la Iglesia americana había hecho un amplio uso de estas disposiciones, el rey observó que las condiciones de necesidad que habían permitido su elaboración y aplicación ya no existían. De hecho, en casi todas las diócesis había ahora presente un clero secular adecuado en número y preparación. Por lo tanto, se ordenó que a partir de ese momento «aviendo clérigos idóneos y suficientes lo proveáis en los dichos curazgos doctrinas y beneficios prefiriéndolos a los frayles y guardándose en la dicha provisión las órdenes que se refiere en el titulo de nuestro patronazgo». ${ }^{5}$ Además, se preveía que en las diócesis en las que no había todavía un número considerado adecuado de sacerdotes para las doctrinas deberían «repartirse entre las órdenes que ay en esas provincias, de manera que haya de todos para que cada uno travaye según su obligación de aventajarse en tan santo apostólico exercicio». En los dos casos, todas las doctrinas de indios eran sujetas al control del obispo «y vos velareis sobre todo como buen pastor» ${ }^{6}$ (Pérez Puente, 2009, p. 91).

5 Copia de la real cédula del 6 diciembre 1583, 30 de marzo de 1588, AGI, Patronato, 248, r. 17. Véase también la real cédula al arzobispo de México y a los demás obispos reunidos en Concilio, 1585, AGI, Indiferente, 427, L 30, ff. 364366, cit. en Pérez Puente (2009, p. 228).

6 Copia de la real cédula del 6 diciembre 1583, 30 de marzo de 1588, AGI, Patronato, 248, r. 17. 
El contenido de la real cédula respondía en parte a las preocupaciones que el arzobispo Mogrovejo había enviado al soberano solo unos meses antes. De esta manera es posible observar cómo en este aspecto las necesidades de la diócesis de Lima coincidían con las de otras diócesis americanas — como las del importante arzobispado de Ciudad de México expresas por el arzobispo Moya de Contreras (Pérez Puente, 2009, p. 92) - y para las cuales se pidió una respuesta a las cuestiones más generales sobre el gobierno espiritual que afectaban a grandes porciones de los territorios americanos.

En la arquidiócesis de Lima la aplicación de las disposiciones contenidas en la real cédula tuvo un comienzo gradual, por voluntad del mismo arzobispo Mogrovejo que, a partir de 1584, había iniciado una nueva y larga visita pastoral en la diócesis (Benito, 2006). De otra parte, la respuesta de las órdenes religiosas a la real cédula de 1583 fue particularmente crítica y dio lugar a fuertes protestas que llevaron al envío de procuradores a la Corte, para informar al rey de los inconvenientes y las dificultades que surgirían de la aplicación de las nuevas reglas (Mazín, 2007; Pérez Puente, 2009). Una actitud de cooperación vino solo de los agustinos, cuyo padre provincial fray Luís López de Solís, en 1585, dejó todas las doctrinas administradas por su orden en la provincia eclesiástica de Lima al virrey conde de Villar, como vicepatrón de la Iglesia americana, facilitando así la sustitución con el clero secular (Rodríguez Valencia, 1958, II, p. 255).

La real cédula de 1583 fue acogida favorablemente por las autoridades civiles, en particular por los cabildos seculares, que se opusieron a las protestas de los religiosos pidiendo que no se negaran las doctrinas a los sacerdotes (Dammert Bellido, 1996, p. 268).

Con el fin de atenuar este incipiente conflicto sobre la sustitución del clero en las diócesis americanas, Felipe II pidió a las órdenes religiosas y a los obispos que le enviaran más información detallada sobre la situación y los posibles efectos que dicha sustitución podría tener en el territorio. Además, según las investigaciones 
de Vicente Rodríguez Valencia, Leticia Pérez Puente y Óscar Mazín, el soberano convocó una junta especial compuesta por diez miembros de la Corte - laicos y clérigos - con la tarea de examinar los memoriales y la información procedente de las diócesis americanas (Rodríguez Valencia, 1958, II, pp. 255-256; Pérez Puente, 2009, p. 99; Mazín, 2010, pp. 170-176).

Tras los numerosos debates e informaciones recibidas por el Consejo de Indias, Felipe II decidió revocar la anterior real cédula del 6 de diciembre de 1583 mediante una cédula suspensiva fechada el 30 de marzo de 1588 y dirigida a todos los obispos y arzobispos de los territorios americanos. En este documento el rey informó que habían llegado a la secretaría del Consejo de Indias «ynformaciones, cartas y relaciones y pareceres que ágora por ocasión de esta carta se han dado enviado y traído de todas partes» procedentes de las órdenes religiosas y de los sacerdotes. En estos documentos se presentaban los negativos efectos de la real cédula de 1583 para la evangelización y el gobierno eclesiásticos de los territorios americanos. Por tanto, el rey pidió nuevas y ulteriores informaciones sobre este delicado asunto, «juntando las personas que os pareciere, y de cuya vida, letras y ejemplo e inteligencia tengáis mas entera satisfacción de que miraran por la honra y servicio de Dios Nuestro Señor y bien de las almas sin advertir a otro fin ni pretensión, tratéis y platiquéis de lo que a esto toca, y me enviéis relación muy particular de lo que os pareciere». ${ }^{7}$

El rey ordenó, por lo tanto, que las doctrinas de indios se dejaran a los religiosos sin que se introdujera ninguna novedad en la presentación y recomendó, además, que el propio obispo visitara:

[...] las yglesias y las doctrinas donde estuvieren los dichos religiosos

$[\ldots]$ y las fabricas de las otras yglesias, $[\ldots]$ y todas las demás cosas

7 Real cédula al arzobispo Mogrovejo, 30 de marzo de 1588, AGI, Patronato, 248, r. 17. 
tocantes a las tales yglesias servicio del culto divino y a los religiosos que estuvieren en las dichas doctrinas ansimesmo los visitareys y corregyreis en quanto a curas fraternalmente teniendo particular cuenta de mirar por el onor y buena fama de los tales religiosos. ${ }^{8}$

Asimismo, se ordenó a los virreyes de Nueva España y Perú, a los presidentes de las audiencias y a los gobernadores «que exercieren nuestro real patronazgo en nuestro nombramientos y promociones la forma, calidades y circunstancias con que se ha practicado en los Reynos del Perú». ${ }^{\text {? }}$

Cuando la nueva disposición llegó a la diócesis de Lima, el arzobispo Mogrovejo todavía estaba completando la larga visita pastoral (1584-1591), que había comenzado después de la conclusión del concilio provincial de 1583 (Benito, 2006). Por lo tanto, los informes posteriores que el arzobispo envió sobre este tema fueron fuertemente influenciados por su observación directa del territorio y las necesidades que él creía que debían ser dignas de la intervención real.

En respuesta a la nueva real cédula, el 13 de marzo de 1589, Mogrovejo envió una relación redactada sobre «lo que tengo visto y entendido en la visita general que ha muchos años voy prosiguiendo en este Arzobispado». En cuanto a la petición del rey de ser informado sobre la conveniencia de que los religiosos continúen administrando las doctrinas de los indios, Mogrovejo respondió que, sobre la base de lo que había podido observar durante su visita pastoral, sería más apropiado que «habiendo clérigos sean preferidos a los frailes». La razón de esta afirmación se refería a la preparación y a la conducta de los sacerdotes, que «atendiendo que a cada año tienen visita y a que con rigor son penados y castigados por sus Prelados, procu-

8 Real cédula al arzobispo Mogrovejo, 30 de marzo de 1588, AGI, Patronato, 248, r. 17.

9 Real cédula al arzobispo Mogrovejo, 30 de marzo de 1588, AGI, Patronato, 248, r. 17. 
ran ser muy observantes». ${ }^{10}$ La substitución de los regulares con el clero secular tenía entonces un valor de gobierno eclesiástico bien definido por Mogrovejo que, junto con la creación de un seminario diocesano, lo consideraba una etapa fundamental para el control parroquial del arzobispado (Pérez Puente, 2009, p. 152).

Estos aspectos se referían tanto al Derecho canónico reformado en Trento como a las decisiones tomadas durante los concilios provinciales de 1567 y 1583 (Vargas Ugarte, 1951), en relación con la reforma del clero y la obligación de que los sacerdotes permanezcan al menos seis años en la doctrina que se les ha confiado. Además, en estas iniciales informaciones, Mogrovejo destacaba la importancia de la facultad de visita in vita et moribus por parte del obispo de las órdenes religiosas residentes en las doctrinas. De hecho, sobre este asunto el arzobispo apeló directamente a la Congregación del Concilio. ${ }^{11}$ En 1584 había enviado a Roma una lista de treinta y siete dudas sobre la aplicación de las normas tridentinas, incluyendo la posibilidad de la visita del ordinario diocesano para los religiosos extra claustra (y, en particular, en las doctrinas) (Rodríguez Valencia, 1958, II, p. 220).

Las respuestas dadas por la Congregación ${ }^{12}$ fueron por lo tanto tomadas en consideración por el rey cuando redactó la real cédula de 1588, que establecía que «los curas religiosos deben ser visitados en todas las cosas que son en officio oficiando» refiriéndose, por tanto, directamente a los decretos del Concilio de Trento. ${ }^{13}$ Por lo tanto, es posible observar cómo las dudas del arzobispo Mogrovejo y las respuestas de la Congregación a su favor fueron recibidas en el proceso

10 Carta de Mogrovejo al rey, 13 de marzo de 1589, AGI, Patronato, 248, r. 17.

11 Carta de Mogrovejo a la Congregación del Concilio, 1584, AGI, Lima, 300; Archivo Apostólico Vaticano (en adelante, AAV), Cong. Concilio, Libri Decretarum, $7 \mathrm{a}, \mathrm{s} / \mathrm{f}$.

12 AAV, Cong. Concilio, Libri Decretorum 4, ff. 112-115.

13 Recopilación, lib. 1, tít.15, 1. 28. 
legislativo más general de la monarquía. La posición adoptada por los cardenales intérpretes del Concilio de Trento no podía, de hecho, ser marginada por la Corona en los aspectos de gobierno de la arquidiócesis de Lima, y tampoco podía ser descuidada en el gobierno eclesiástico, dado que las disposiciones de la Congregación asumían el carácter de una norma general. A pesar de ello, el arzobispo encontró cada vez más dificultades en estas visitas, ya que los religiosos tendían a obstaculizarla, negándose a ser definidos como párrocos, subrayando en cambio su pertenencia a una orden monástica.

A partir de los años noventa hasta su muerte en 1606, coincidiendo con la creciente dificultad de visitar las doctrinas gobernadas por religiosos, Mogrovejo abordó varias veces en su correspondencia con el rey la posibilidad de completar el proyecto de sustituir el clero regular por el secular en las doctrinas de indios; aún más porque, a lo largo de los años, el estado del clero secular había mejorado en cantidad y calidad. La cuestión fue también abordada por el IV Concilio Provincial de Lima (1591) (Vargas Ugarte, 1951), ${ }^{14}$ que «exigió el respeto a la jurisdicción de los obispos, respaldando sus determinaciones en la Congregación de Cardenales intérpretes del Concilio de Trento» (Pérez Puente, 2009, p. 154).

Regresando de la primera visita pastoral, Mogrovejo escribió varias cartas al soberano y al Consejo de Indias sobre las necesidades observadas en el territorio, pidiendo a la Corona una intervención directa para el buen gobierno de la diócesis y el bien espiritual de sus fieles. Dentro de esta rica correspondencia el arzobispo se ocupó del estado del clero secular en la diócesis, una situación profundamente diferente a la que se había presentado durante el Tercer Concilio de Lima en 1583. Cuando llegó a Lima en 1581, a los ojos del nuevo arzobispo había una situación de escasez, humana e intelectual, de sacerdotes en toda la provincia eclesiástica del Perú.

14 Las actas del IV Concilio de Lima se encuentran también en AAV, Congr. Riti Proc. 1612, ff. 75 y ss. 
Durante las sesiones del concilio la intención era facilitar el acceso al sacerdocio, derogando las disposiciones previstas por el arzobispo Jerónimo de Loaysa que preveían la ordenación de sacerdotes para los indios con la restricción de que ya se les había asignado una doctrina (Tineo, 1990; Vargas Ugarte, 1951). Tanto más porque las características y el origen del clero americano habían cambiado profundamente desde la mitad del siglo: de un clero procedente principalmente de España se estaba reemplazando a un clero nacido y ordenado directamente en América.

En 1593, el tenor de las observaciones del arzobispo Mogrovejo adquirió un significado muy diferente. En diez años el número de sacerdotes se había multiplicado, apoyado también por una mejor preparación (Rodríguez Valencia, 1958, II, pp. 102-105). Esta situación, paralela al fracaso de la sustitución de los religiosos en las doctrinas, llevó al desempleo y a la pobreza material de los sacerdotes. En mayo de ese mismo año esta nueva realidad fue presentada al rey por el arzobispo, quien pidió una intervención para frenar la pobreza del clero a través de una decisiva intervención de la Corona (Maldavsky, 2012, p. 171; Dammert Bellido, 1996, p. 247). ${ }^{15}$ Mogrovejo lamentaba el estado de extrema pobreza de los sacerdotes desempleados, que «mueren de hambre y andan buscando misas que decir para poderse sustentar y están alojados en mesones por no tener doctrinas». ${ }^{16} \mathrm{El}$ tema volvió a abordar la cuestión de las órdenes religiosas en la doctrinas, ya que estas no podían ser administradas por el clero secular ya que un buen número estaba ocupado por religiosos. Según lo que se observó en la visita que acababa de concluir, 121 doctrinas pertenecían a los religiosos y solo 98 a los sacerdotes.

Por lo tanto, para Mogrovejo habría sido conveniente que los religiosos dejaran las doctrinas que les habían sido concedidas du-

15 Carta de Mogrovejo al rey, 8 de mayo de 1593, AGI, Patronato, 248, r. 28 (51); cfr: AAV, Cong. Conc., Relat. Dioc. 450, Limana, f. 338v.

16 Carta de Mogrovejo al rey, 8 de mayo de 1593, AGI, Patronato, 248, r. 28 (51). 
rante una situación de escasez de sacerdotes, que en la actualidad se podía decir que había cesado. Además, el confiar las doctrinas al clero secular habría mejorado también la administración y el control por parte del obispo, dado que la visita in vita et moribus era de su competencia y tenía la posibilidad de controlar su trabajo en la administración de los sacramentos, la aplicación de los concilios provinciales y de los sínodos diocesanos, y la buena conducta de los sacerdotes. ${ }^{17} \mathrm{La}$ rivalidad entre el clero secular y el regular por la administración de las doctrinas y la consiguiente posibilidad del obispo de controlar el trabajo de los doctrineros, en la carta de Mogrovejo, también asumieron un carácter más general en cuanto a la presencia de los religiosos en la diócesis. De hecho, escribió al rey:

[...] paréceme podría excusar Vuestra Alteça de imbiar mas friales acá gastando tanto con ellas y que de los que acá están se fuesen gran parte dellos a poblar los conventos de estas partes y que no hubiese tanto numero de ellos en cada convento como ágora ay que esto les debe de poner en la necesidad. ${ }^{18}$

Con el paso de los años, el número de clérigos seculares había aumentado considerablemente, y como no podían presentarse en las doctrinas de indios se encontraron sin empleo, creando un estado de grave necesidad en la arquidiócesis (Rodríguez Valencia, 1958, II, pp. 102-105; Dammert Bellido, 1996, p. 247). Los temas de la substitución del clero regular con el secular y las necesidades debidas a la pobreza del clero secular eran evidentes no solo en la diócesis de Lima, sino también en la de Cusco y Las Charcas y en las diócesis de Chile.

Las consideraciones y peticiones de Mogrovejo en relación con este asunto fueron tomadas en consideración por el Consejo de Indias en noviembre de 1595, cuando el rey envió algunas res-

17 Carta de Mogrovejo al rey, 8 de mayo de 1593, AGI, Patronato, 248, r. 28 (51).

18 Carta de Mogrovejo al rey, 8 de mayo de 1593, AGI, Patronato, 248, r. 28 (51). 
puestas a las cartas del virrey Hurtado de Mendoza y del virrey Velasco. En esta consulta, el Consejo sugirió al soberano que ordenara al virrey Velasco que considerara con el arzobispo y la audiencia si sería conveniente privar a los religiosos de las doctrinas de indios en favor del clero secular. ${ }^{19}$

Mogrovejo trató, una vez más, la cuestión de la sustitución de los religiosos en las doctrinas en una correspondencia con el rey en 1602, durante la cuarta y última visita pastoral (1601-1606). En este caso, el arzobispo abordaba estos aspectos en referencia no solo al gobierno de la diócesis, sino también en relación con las posibles soluciones para hacer frente a la pobreza del clero secular.

El 29 de abril de 1602, Mogrovejo escribió al rey sobre algunos aspectos del gobierno de la Iglesia y la administración de las doctrinas, en relación con algunos abusos de los corregidores de indios y la explotación a la que estaban sometidos los indios. Al final de la carta, también abordó los aspectos relativos a la sustitución del clero:

[...] escrito tengo algunas vezes el mucho numero de clérigos que en este arcobispado ay extravagantes y la necesidad que padescen en razón de tener los frayles ocupados las mas doctrinas y que me astengo y he abstenido de ordenar sino solamente a los que tienen beneficios o capellanías con que se sustentar conforme al santo Concilio de Trento para que no anden mendigando como lo hazen los mas clérigos. ${ }^{20}$

Esta situación podría haberse resuelto fácilmente si solo «los frayles dexassen las doctrinas»; el arzobispo pidió por lo tanto al rey «de poner en todo el remedio que es necesario». ${ }^{21}$

19 Consultas originales del Consejo (1575-1603), AGI, Lima, 1.

20 Carta de Mogrovejo al rey, 29 de abril de 1602, AGI, Patronato, 248, r. 33 (3).

21 Carta de Mogrovejo al rey, 29 de abril de 1602, AGI, Patronato, 248, r. 33 (3). 
En otra carta del mismo año, Mogrovejo nuevamente reflexionaba sobre el estado de necesidad en que se encontraba el clero secular, reiterando una vez más que la pobreza del clero secular era una consecuencia de su desocupación, «en razón de tener los frayles las mas doctrinas». ${ }^{22}$

Refiriéndose a las peticiones del rey de recibir información de la alta jerarquía eclesiástica sobre la posible sustitución del clero regular por el secular en las doctrinas, Mogrovejo envió en la carta algunas opiniones al respecto. Con referencia a la facultad de administración de las doctrinas de indios por parte de los religiosos, el arzobispo señaló que las concesiones de los pontífices se habían dado en un contexto muy diferente al actual, en el que los obispos necesitaban a los religiosos para llevar a cabo la evangelización. Luego añadió que:

[...] ágora ay tantos de los hijos de la tierra y legítimos patrimoniales que no tiene a que aspirar sino a una doctrina y faltándoles no ay para que estudiar aplicarse a cosas de la iglesia sino a ser soldado y salteadores y no ay necesidad de seminarios ni que los obispos hagan órdenes pues no tiene que darle sestando como están los religiosos en ella y para conservación de sus religiones ympetrará mucho se recogan los frayles a ellas donde tendrán el descanso y recogimiento que por ellos se desea. ${ }^{23}$

Una vez más, el arzobispo señaló que, si las doctrinas se hubieran concedido solo a los sacerdotes, él habría tenido mayor facilidad para cumplir sus obligaciones de visitar a los religiosos tanto in vita et moribus como en los muchos aspectos del ministerio pastoral, quitando del cargo o castigando a los religiosos que no lo hicieran. Como en cartas anteriores, por lo tanto, concluyó la carta pidiendo una intervención real:

22 Carta de Mogrovejo al rey, 30 de abril de 1602, AGI, Patronato, 248, r. 33 (11).

23 Carta de Mogrovejo al rey, 30 de abril de 1602, AGI, Patronato, 248, r. 33 (11). 
Vuestra Magestad será servido mirarlos con buenos ojos para que con brevedad se acuda al remedio que conviene y las visitas se hagan enteramente con la libertad que es razon y en todo se descargue la conciencia de todos. ${ }^{24}$

En el asunto de la sustitución del clero regular por el secular también intervinieron los virreyes del Perú don García Hurtado de Mendoza y don Luis de Velasco, tomando una posición similar a la del arzobispo. En 1594, don García Hurtado de Mendoza, en su correspondencia con la Corona, subrayó la necesidad de que las doctrinas se entregaran definitivamente al clero secular y que los religiosos volvieran a sus conventos. Al igual que el arzobispo, el virrey observó que «hay gran cantidad de sacerdotes de la orden de San Pedro y cada día se van ordenando otros y no tiene con qué se poder sustentar» (Bayle, 1950, pp. 6-7). A continuación, recordó que la razón que impulsaba a la Corona a conceder doctrinas al clero regular era la falta de seculares, que en el contexto actual podría considerarse obsoleta. Además, añadió que «los frailes graves y desinteresados, generalmente de todas las órdenes, desean mucho esto». ${ }^{25}$

Observaciones similares fueron hechas también por don Luis de Velasco, que en 1600 propuso al rey «poner las doctrinas en clérigos idóneos y mandar recoger los frailes a sus conventos, de donde podrían si quisieren salir a predicar y enseñar a los naturales y otras misiones». ${ }^{26}$ De este modo se habría resuelto varios problemas relacionados con el desempleo de los seculares y la preparación del clero de las doctrinas.

A pesar de las numerosas informaciones enviadas por el arzobispo, sus peticiones de una intervención decisiva de la Corona a favor de los sacerdotes y el apoyo de los virreyes Hurtado de

24 Carta de Mogrovejo al rey, 30 de abril de 1602, AGI, Patronato, 248, r. 33 (11).

25 Carta del virrey García Hurtado de Mendoza al rey, 12 de abril de 1594, AGI, Lima, 33.

26 Carta del virrey Velasco al rey, 5 de mayo de 1600, AGI, Lima, 33. 
Mendoza y Velasco, el rey no derogó la real cédula de 1588. Esta posición también se mantuvo en el siglo XVII, como puede verse en la Recopilación de Leyes de Indias, que incluía no solo las disposiciones de Felipe II de 1588, sino también las reales cédulas de Felipe III y Felipe IV que las confirmaban. ${ }^{27}$

A partir de los años veinte del siglo XVII, por un lado, la Corona favoreció de manera clara un modelo de Iglesia propiamente diocesano, dictando dos importantes reales cédulas sobre doctrinas de indios en $1624^{28}$ y en $1634 .{ }^{29}$ En estas se establecieron "procedimientos y límites claros en la actuación de frailes y obispos, encaminados a la guarda de los derechos patronales». Del otro lado, la cuestión de la sustitución del clero regular por el secular no se resolvió definitivamente hasta la mitad del siglo XVIII, aunque hubo algunos intentos de reforma como el del obispo Juan de Palafox que, en 1641, inició la secularización en la diócesis de Puebla (Pérez Puente, 2009, pp. 178179). Sin embargo, esto no implicaba una aceptación pacífica de la situación en las doctrinas de indios, como puede verse en las cartas del virrey conde de Montesclaros y en las actas de gobierno eclesiástico del arzobispo de Lima, Bartolomé Lobo Guerrero, quien pretendía examinar a los prelados antes de la toma de posesión de las doctrinas, como era ordenado por una real cédula de $1603^{30}$ (Pérez Puente, 2009, pp. 180-182). Él cumplió la orden dada en 1595 de enviar información sobre el número de religiosos, conventos, haciendas y doctrinas. Además de razones relacionadas con la recaudación de los diezmos, la información debía servir para ordenar la reducción del número de conventos, ya que la limosna que la Corona daba a las

27 Recopilación, lib. 1, tít. 15, 1. 28.

28 Real cédula, 1624, Biblioteca Nacional de España (BNE), ms. 3047, ff. 167r-167v, cit. en Pérez Puente, 2009, pp. 235-237.

29 Real cédula al duque de Escalona y al marqués de Alderete, virreyes de Nueva España, 1634, AHN, Osuna, CT. 7, D. 4 (1-5), cit. en Pérez Puente, 2009, pp. 238-239.

30 Real cédula al arzobispo de Los Reyes, 1603, cit. en Pérez Puente, 2009, pp. 231-232. 
doctrinas había aumentado mucho. En 1612, paralelamente a estos, también se envió un informe en el que se destacaban las dificultades del virrey para reunir este tipo de información (Latasa Vassallo, 1997, p. 199; 2013, pp. 595-598). ${ }^{31}$

También la Congregación de Propaganda Fide, a través de su red de informadores, se interesó en la cuestión. Desde 1630, hasta mediados de siglo, un tema que se repetía a menudo en los memoriales y en las informaciones que llegaban a Roma era el de las doctrinas administradas por el clero regular. En principio, la Congregación habría estado a favor de la secularización de las doctrinas, pero recibió de sus informadores —en su mayoría pertenecientes al clero regular - opiniones negativas acerca de las consecuencias que podrían ocurrir para la salud espiritual de los indios. En particular, las órdenes religiosas temían el creciente control de los obispos, quienes, dependiendo de la Corona, habrían reducido las libertades concedidas a las órdenes permitiendo una extensión aún mayor de la jurisdicción real sobre los asuntos eclesiásticos (Sanfilippo y Pizzorusso, 2004, p. 94).

Finalmente, a mediados del siglo XVIII, el pontífice intervino directamente sobre la posibilidad de sustitución para fijar de manera definitiva la disciplina canónica de los religiosos en las doctrinas de indios. En particular, el papa Benedicto XIV intervino en tres puntos fundamentales decidiendo la jurisdicción del obispo en la cura de almas (visita local), la jurisdicción sobre la vida privada y las costumbres de los párrocos religiosos (visita personal) y la administración de las doctrinas por el clero secular. Estas decisiones se emitieron mediante bulas y breves: Quamvis ad confirmandum (1745) sobre la jurisdicción; Firmandis atque asserendis (1744) sobre la visita in vita et moribus; Cum Nuper (1751), que regulaba algunos aspectos de la administración y el gobierno de las doctrinas de indios por parte del clero secular (Rodríguez Valencia, 1958, II, p. 270).

31 Carta del virrey Montesclaros al rey, 1 de abril de 1612, AGI, Lima, 36. 
Paralelamente a las decisiones tomadas por la Santa Sede, la Corona también intervino para resolver la cuestión. En 1749, Fernando VI se pronunció a favor de la sustitución del clero regular por el secular en las doctrinas de indios (García Añoveros, 1990, pp. 151-152).

\section{El NÚMERo DE LOS CURAS EN LAS DOCTRINAS DE INDIOS}

Vinculado al tema de las doctrinas de indios, en la correspondencia entre Mogrovejo y el rey, otro tema que se trató repetidamente fue el del número de curas de indios en las doctrinas, considerado inadecuado a las necesidades encontradas. El aumento de los curas de indios, junto con la sustitución de los religiosos en las doctrinas, podría haber enfrentado el problema del gran número de seculares desempleados. Aunque el problema del desempleo del clero era bien conocido en las diócesis americanas, no fue hasta el III Concilio de Lima, en 1583, que se buscaron soluciones adecuadas. En particular, en los capítulos 10 y $11^{32}$ de la sesión III se propuso reducir el número de indios por doctrina de cuatrocientos a trecientos, aumentando el número de repartimientos (Acosta, 2014, pp. 244-245). Sin embargo, esto no condujo a una solución inmediata.

En el informe enviado tras la visita pastoral de 1582, Mogrovejo lamentaba el evidente estado de necesidad del clero. ${ }^{33} \mathrm{El}$ asunto se retomó en la carta del 10 de abril de 1588, en la que se observaba la presencia de un número excesivo de indios por doctrina y se pedía que las autoridades civiles colaborasen en la ejecución de lo dispuesto por el concilio, que:

32 III Concilio de Lima (1583), ss. III, caps. 10, 11.

33 Carta de Mogrovejo al rey, 25 de febrero de 1583, AGI, Patronato, 248, r. 5. 
[...] ordenó y proveyó que en cada doctrina de dozientos o trezientos tributarios se pusiese y hubiese un sacerdote [...]. Así por el derecho antiguo como por los nuevos de cierto del santo concilio tridentino se avisa en carescidamente a los obispos que no consientan que un cura se encargue de mas feligreses de lo que puede regir administrándoles los sacramentos y haziendo lo demás que pertenece al culto divino. ${ }^{34}$

La falta de curas no permitía que todos los sacramentos fueran administrados dignamente a los indios, impidiendo la misión evangelizadora de la Corona:

$[\ldots]$ lo he visto y entendido por la visita que he hecho y en particular de un repartimiento [...] que tiene novecientos y cincuenta yndios tributarios ultra dellos reservados e son los caciques y principales. ${ }^{35}$

Esta situación podría haber sido remediada mediante el uso de tributos, que se estimaron suficientes para poder nombrar a otros sacerdotes en las doctrinas. El arzobispo pidió entonces al rey que interviniera, enviando reales cédulas al virrey, a las audiencias y a los gobernadores para que se encargaran de poner en práctica lo dispuesto por el concilio de $1583 .{ }^{36}$ Por una anotación en el margen de la carta, parece que el rey aceptó las peticiones de Mogrovejo: «dese cedula en esta conformidad». ${ }^{37}$

A pesar de ello, las carencias del clero seguían siendo evidentes, tanto que en la correspondencia relativa al IV Concilio de Lima de 1591, enviada a la Corte a través del licenciado Castillo, Mogrovejo volvió a pedir una acción incisiva del rey sobre el número de indios para cada doctrina. ${ }^{38}$ De nuevo la Corona escuchó las peticiones del

34 Carta de Mogrovejo al rey, 10 de abril de 1588, AGI, Patronato, 248, r. 18.

35 Carta de Mogrovejo al rey, 10 de abril de 1588, AGI, Patronato, 248, r. 18.

36 Carta de Mogrovejo al rey, 10 de abril de 1588, AGI, Patronato, 248, r. 18.

37 Carta de Mogrovejo al rey, 10 de abril de 1588, AGI, Patronato, 248, r. 18.

38 Toribio Alfonso Mogrovejo: Concilio Provincial de Lima, 1592, 1595, AGI, Patronato, 248 , r. 23. 
arzobispo y, en diciembre de 1592, entre las respuestas dadas con ocasión de un informe enviado durante la segunda visita pastoral, se abordó también el aspecto relativo a las doctrinas y al número de curas de indios. ${ }^{39}$

Además, tomando como referencia una real cédula del 25 de julio de 1593, la Recopilación de Leyes de Indias de 1681 establecía:

Porque conviene señalar el numero de indios que cada doctrinero en cada provincia de tener a su cargo para doctrinar y ensenar en las cosas de nuestra sancta fe cathólica es nuestra voluntad que los Arcobispos y obispos cada uno en su diócesis con parecer del nuestro virrey o governador de la provincia, tasen y moderen en cada una los indios que será bien que tenga cada doctrina en ésta procurando que no pasen de quatrocientos indios los que cada doctrinero tubiere a su cargo si no es que la tierra i disposición de los pueblos requiera que en algunos sean mas o menos. ${ }^{40}$

Sin embargo, el excesivo número de fieles por doctrina no se resolvió definitivamente y, en 1604, Mogrovejo escribió al rey pidiendo el envío de cédulas que hicieran efectivas las decisiones:

[...] cada pueblo que tiene doscientos o trescientos yndios aya un sacerdote y cuando no huviere tanto numero se reduzcan a otro pueblo donde se pueda cumplir el dicho numero [...] Vuestra Magestad sea servido despachar vuestra real cedula apretada para que así se haga y cumpla que vuestros virreyes y audiencias den favor y ayuda. ${ }^{41}$

El rey tomó en consideración este asunto también en las Instrucciones dadas al virrey Luis de Velasco (1595), en las que se le advertía del aumento del número de doctrinas y haciendas administradas por religiosos y se le reiteraba la obligación de enviar un

39 Real cédula al arzobispo Mogrovejo, 23 de diciembre de 1592, AGI, Patronato, 248, r. 17.

40 Recopilación, lib. 1, tít. 6, 1. 10.

41 Carta de Mogrovejo al rey, 10 de mayo de 1604, AGI, Patronato, 248, r. 37 (4). 
informe al Consejo (Acosta, 2014, p. 254). Además, se envió una real cédula al virrey el 3 de mayo de 1595, en la que el soberano pidió que se le informara con más detalle sobre la posibilidad de «dividir las dichas parroquias y hacer yglesias de nuevo y en que partes y en caso que conviniese hazerlas por que orden y forma se podera hazer y si ay falta en la administración de sacramentos y doctrina de los yndios». ${ }^{42}$

En los informes redactados durante sus visitas pastorales a la diócesis, además de la oportunidad de aumentar el número de sacerdotes empleados en las doctrinas, Mogrovejo también señaló la posibilidad de enviar sacerdotes a los obrajes, los primeros ejemplos de fábricas textiles cuya regulación se debe a las Ordenanzas del virrey Toledo (Merluzzi, 2014), donde se debía proveer a la salud espiritual de los trabajadores (Lockhart y Schwartz, 1992, pp. 137141). ${ }^{43}$ Un primer y detallado informe sobre los contactos entre el arzobispo y estos primeros talleres textiles fue enviado al rey por Francisco de Quiñones en abril de 1587.

Durante la visita, Mogrovejo y su comitiva se encontraron con muchos indios, hombres y mujeres, que llevaban grandes cantidades de lana, y cuando el arzobispo les preguntó a dónde iban, respondieron que iban a los obrajes. Deseando visitar también esos lugares, Mogrovejo entró y vio a un gran número de indios de doce o trece años de edad que estaban hilando, mientras que otros más viejos estaban cardando lana y, por lo tanto, preguntó sobre el trabajo y las ganancias de cada uno. Al final de su visita quedó profundamente impresionado, tanto que escribió al rey para que interviniera para moderar la explotación de los indios por parte de los corregidores encargados de las manufacturas. ${ }^{44}$

42 Real cédula al virrey y Audiencia de Lima, 3 mayo 1605, AGI, Lima, 570, 1. 16, f. $145 \mathrm{r}$.

43 Recopilación, lib. 4, tít. 26.

44 Carta de Quiñones al rey, 4 de abril de 1587, AGI, Lima, 248, r. 15. 
La influencia de las sugerencias del arzobispo para algunas intervenciones de carácter social fue tomada en consideración por el Consejo de Indias y el soberano, particularmente en lo referido a la condición de los trabajadores. A principios del siglo XVII, el arzobispo sugirió, de hecho, que:

[...] importará asimismo que en los obrajes y haciendas de los indios donde hay algunos de ellos que las pueden gobernar y administrar se diese orden no hubiese administradores que les consuman las haciendas con salario que se les señalan y que lo que se diese de los dichos obrajes y haciendas se gastase en beneficio de los indios, y que gozasen de lo que fuese suyo cada uno como le cupiese. ${ }^{45}$

Al margen de estas consideraciones, el Consejo de Indias elaboró su opinión en una consulta al rey: «que informa el virrey y Audiencia con su parecer, y que entre tanto provean como los indios no sean vejados ni agraviados, y lo demás quel es pareciere convenir a su bien y a la buena administración de justicia y al buen gobierno». ${ }^{46}$

Junto con sus denuncias de la explotación de los indios en los obrajes, Mogrovejo también se preocupaba por asegurar que los indios que trabajaban allí recibieran una asistencia espiritual adecuada. En efecto, durante su visita al obraje, en 1587, el arzobispo fue informado de la falta de enseñanza de la doctrina cristiana en esos lugares y, por tanto, entre las peticiones enviadas a Madrid a través del doctor Castillo, Mogrovejo discutió también la posibilidad de enviar sacerdotes a los numerosos «injenios de azucar y obrajes de paños y cordelletes» presentes en la diócesis. El arzobispo observó cómo los indios elegidos para trabajar en los obrajes eran desarraigados de sus propios pueblos y enviados a trabajar a lugares lejanos, donde apenas recibían una asistencia espiritual adecuada.

45 Carta de Mogrovejo al rey, 1602, AGI, Patronato, 248, r. 33.

46 Carta de Quiñones al rey, 4 de abril de 1587, AGI, Lima, 248, r. 15. 
El arzobispo señaló, en efecto, que en cada «obraje e ingenio» podían trabajar más de cien indios, a los que se podían sumar también sus mujeres e hijos, alcanzando así una población total de más de trescientas personas. Por lo tanto, el arzobispo sugirió al rey que nombrara un sacerdote que tuviera la autoridad de predicar, enseñar la doctrina y administrar los sacramentos, con un salario suficiente para su propia supervivencia y los ornamentos necesarios para la iglesia y su ministerio, a expensas de los propietarios de las «haciendas»y los obrajes. ${ }^{47}$

Como había sucedido con las denuncias de explotación de los nativos, también en este caso la Corona intervino para salvaguardar la salud espiritual de sus súbditos mediante una real cédula del 20 de junio de 1592 que, posteriormente, fue recopilada en la Recopilación de Leyes de Indias:

Otrosí ordenamos y mandamos que si a nuestros virreyes y gobernadores pareciere que los indios de obrages de paños e ingenios de azucar no tiene doctrina, y que no es bastante remedio acudir a otra por cercanía, hallando que conviene ponérsela en forma, den orden que con parecer de su prelado se haga por cuenta de los dueños de obrage y encomenderos. ${ }^{48}$

Esta real cédula confirmaba implícitamente una anterior de 1541, en la que el soberano había ordenado que no se impidiera a los indios ni a los esclavos negros asistir a los servicios religiosos, garantizando un día de descanso los domingos y durante «las fiestas de guardar». ${ }^{49}$ También se vincularon a esto las decisiones tomadas durante el Tercer Concilio de Lima, en la sesión II, capítulo 5, en que se decretó que los párrocos debían reunir a los niños y a los

47 Toribio Alfonso Mogrovejo: Concilio Provincial de Lima, 1592 y 1595, AGI, Patronato, 248, r. 23.

48 Recopilación, lib. 1, tít. 1, 1. 11.

49 Recopilación, lib. 1 tít. 1, 1. 17. 
esclavos para impartirles la doctrina cristiana y, asimismo, los padres de familia debían ser responsables de la instrucción religiosa de sus propias familias y de los esclavos. ${ }^{50}$ Además, dentro de las disposiciones sinodales elaboradas durante las visitas pastorales del arzobispo, se ordenaba que los curas de indios dijeran dos misas todos los domingos y días festivos. ${ }^{51}$

\section{Conclusiones}

Para la Monarquía Hispánica la recolección de información, la elaboración del conocimiento del territorio y su circulación eran una parte constitutiva de la negociación del poder político y del propio gobierno. Según el historiador Arndt Brendecke existía, de hecho, una relación concreta entre el poder y el conocimiento, que no podía reducirse a una mera transferencia de información de un lado del Atlántico al otro. Una vez llegada, la información siguió un proceso de elaboración dentro de los órganos político-administrativos de la monarquía y de interpretación de los actos comunicativos de los actores involucrados, cuyas instancias fueron consideradas. Además, no se deben olvidar las características mismas de estos mediadores, que no pueden definirse como neutrales o imparciales. Ellos hicieron saber a la Corona sus intereses y solicitudes, sus consideraciones personales sobre ciertas cuestiones, así como sus observaciones y juicios personales en relación con otros funcionarios reales presentes en el territorio (Brendecke, 2016, pp. 256-260). En particular, este último aspecto marcó las no siempre fáciles relaciones entre las autoridades civiles y la jerarquía eclesiástica en el virreinato del Perú.

50 III Concilio de Lima (1583), ss. II, cap. V.

51 Sínodos diocesanos de Lima, AAV, Congr. Riti, Processi, vol. 1612. 
Para que esta circulación de información permitiera a la Corona compensar la parcialidad de su propio conocimiento en la elaboración de decisiones políticas y estrategias de gobierno, era necesario, por lo tanto, que las distancias fueran superadas por técnicas de comunicación y mediadores fiables, convirtiéndose realmente en los ojos y oídos del rey (Brendecke, 2016, p. 86). En el panorama político institucional del Perú de los siglos XVI y XVII, esta delicada tarea era llevada a cabo no solo por el virrey y los funcionarios reales, sino también por la jerarquía eclesiástica, compuesta de regulares y seculares, que necesariamente se relacionaban con los diversos funcionarios de la Corona (Solano, 1991, p. 58; Sánchez Bella, 1995, pp. 263-265; Artola Renedo, 2017, pp. 187-200).

Como hemos visto, para tomar decisiones sobre el gobierno de los territorios americanos, el rey y el Consejo de Indias invitaron insistentemente a la jerarquía eclesiástica a enviar información e informes a Madrid. Una solicitud que se convirtió en ley con una real cédula de 1595. Esta obligó a los prelados a enviar, con cada flota que salía, una «relación muy particular» sobre el estado de la diócesis, sobre el trato reservado a los indios y sobre las acciones del gobierno eclesiástico ejercido por las autoridades civiles presentes en el territorio. ${ }^{52}$ Esta colaboración de los eclesiásticos nunca debió convertirse en una interferencia en los asuntos de gobierno temporal, como recordó Felipe II a los obispos americanos en $1590 .^{53}$

De la correspondencia del arzobispo Mogrovejo ha surgido cómo el prelado estaba perfectamente insertado en este sistema. El contenido de sus cartas se refería a cuestiones religiosas y eclesiásticas, con una particular y siempre viva atención a las relaciones no solo con sus obispos sufragáneos y órdenes religiosas, sino también y sobre todo con el virrey y los demás funcionarios reales en el territorio. Los protagonistas de su diálogo con la Corona fueron sus

52 Recopilación, lib. 6, tít. 10, 1. 7.

53 Recopilación, lib. 1, tít. 14, 1. 66. 
fieles y el progreso de la evangelización, la administración de las doctrinas y el gobierno de todo el territorio diocesano. La información derivada de la observación directa del territorio mediante visitas pastorales había permitido al arzobispo obtener la sensibilidad y la autoridad adecuadas para poder solicitar soluciones legislativas a los problemas que se planteaban en el gobierno del territorio y en el mandato pastoral. Por lo tanto, es posible ver cómo las opiniones personales de Mogrovejo se diluyen en la presentación del contexto social, religioso o institucional que precede a las solicitudes, que suelen concluir el párrafo o todo el escrito.

$\mathrm{Al}$ arzobispo le interesaba presentar al rey lo que se observaba en las visitas pastorales y los problemas que surgían en la evangelización de los indios, en los abusos del clero o de los corregidores, o en la relación con las instituciones. La solicitud directa de una intervención real en la situación ilustrada fue entonces una consecuencia de la descripción del territorio. De esta manera, Mogrovejo pudo justificar sus peticiones, ya que no se limitaban a reflejar su punto de vista, sino que querían presentar la realidad diocesana directamente al soberano. Por lo tanto, el rey y el Consejo de Indias se habrían visto inevitablemente obligados a pronunciarse a favor de las observaciones y de las sugerencias de Mogrovejo. De hecho, habría sido la objetividad de la descripción del estado de la diócesis lo que habría requerido la determinada intervención real. Esta estrategia del arzobispo parece haber dado resultados positivos, como se puede ver en las numerosas reales cédulas - posteriormente recopiladas en la Recopilación de Leyes de Indias — en las que se puede percibir el eco de las palabras y peticiones del arzobispo.

Sin embargo, no debemos cometer el error de considerar esta práctica como un procedimiento siempre satisfactorio. En varias ocasiones el Consejo de Indias no se pronunció a favor de las solicitudes y, por consiguiente, no envió la consulta correspondiente al rey; en otros casos, fue el propio soberano el que no intervino en un asunto concreto porque se consideró que no era estrictamente 
necesario. Además, algunas de las peticiones del arzobispo, para ser satisfechas plenamente, requerían la intervención no solo del Consejo de Indias, sino también de otras instituciones de la monarquía o, en el caso de aspectos estrictamente relacionados con la esfera espiritual, era necesaria la intervención de la Santa Sede, lo que hacía incierto el resultado final del proceso de toma de decisiones.

Como arzobispo de Lima, Mogrovejo se movió en un contexto complejo y articulado de poderes, en un diálogo continuo con la Corona y las demás instituciones políticas presentes en el territorio, pasando así a formar parte plenamente del proceso de toma de decisiones siempre en curso dentro de la Monarquía Hispánica. Esta era una característica dictada por el carácter casuista del Derecho indiano, gracias al cual la Corona tenía la posibilidad de adaptar la ley a la realidad americana para garantizar el buen gobierno. El rey, el Consejo de Indias y las autoridades presentes en el territorio respondieron constantemente a una impresionante masa de informes, memoriales y peticiones provenientes de diferentes sujetos, tanto laicos como eclesiásticos. El arzobispo de Lima, como cabeza de la jerarquía eclesiástica del Perú, se convirtió así en un nodo fundamental de la red de relaciones e información que vinculaba al virreinato con la Corona y los distintos territorios de la monarquía.

\section{REFERENCIAS}

\section{FUENTES DE ARCHIVO}

Archivo Apostólico Vaticano (AAV), Ciudad del Vaticano

AAV, Cong. Concilio, Libri Decretarum, $7 \mathrm{a}$.

AAV, Cong. Concilio, Libri Decretorum 4.

AAV, Cong. Conc., Relat. Dioc. 450, Limana.

AAV, Congr. Riti Proc., vol. 1612.

Archivo General de Indias (AGI), Sevilla

AGI, Indiferente, 427, L 30. 
AGI, Lima, 1.

AGI, Lima, 33.

AGI, Lima, 36.

AGI, Lima, 248, r. 15.

AGI, Lima, 300.

AGI, Lima, 570, 1. 16, f. 145r.

AGI, Patronato, 248, r. 5.

AGI, Patronato, 248, r. 8.

AGI, Patronato, 248, r. 17.

AGI, Patronato, 248, r. 18.

AGI, Patronato, 248, r. 23.

AGI, Patronato, 248, r. 28.

AGI, Patronato, 248, r. 33.

AGI, Patronato, 248, r. 37.

Archivo Histórico Nacional (AHN), Madrid

AHN, Osuna, CT. 7, D. 4 (1-5).

Biblioteca Nacional de España (BNE), Madrid BNE, ms. 3047.

\section{Bibliografía}

Acosta, Antonio (2014). Prácticas coloniales de la Iglesia en el Perú, siglos XVIXVII. Sevilla: Aconcagua.

Albani, Benedetta, Otto Danwerth y Thomas Duve (eds.) (2019). Normatividades e instituciones eclesiásticas en el virreinato del Perú, siglos XVI-XIX. Frankfurt am Main: Max Planck Institute for European Legal History.

Armas Medina, Fernando (1952). «Evolución histórica de las doctrinas de indios». Anuario de Estudios Americanos, vol. 8, pp. 1-46.

Artola Renedo, Andoni (2017). «El obispo, la Monarquía, los poderes locales. La política de destinos episcopales en la segunda mitad del siglo XVIII». En: Michel Bertrand, Francisco Andújar Castillo y Thomas Glesener (eds.). Gobernary reformar la Monarquia; los agentes politicos y administrativos en España y América. Siglos XVI-XIX. Valencia: Albatros Ediciones, pp. 187-200. 
Un EJEMPLO DE INTERACCIÓN JURídica ENTRE LA IgLESIA Y LA CORONA. LA PARTICIPACIÓN DEL ARZOBISPO

Toribio Mogrovejo en el proceso de toma de decisión de la Monarquía Hispánica (1580-1606)

Barrios Pintado, Feliciano (2015). La gobernación de la monarquía de España: consejos, juntas y secretarios de la administración de corte (1556-1700). Madrid: Agencia Estatal Boletín Oficial del Estado.

Bayle, Constantino (1950). El Clero secular y la evangelización de América. Madrid: Instituto de Santo Toribio Mogrovejo; CSIC.

Benito, José Antonio (ed.) (2006). Libro de visitas de Santo Toribio de Mogrovejo (1593-1605). Lima: Pontificia Universidad Católica del Perú.

Bravo Guerreira, María Concepción (1990). «El clero secular en las doctrinas de indios del virreinato del Perú, siglo XVI». En: Josep-Ignasi Saranyana, Primitivo Tineo, Antón M. Pazos, Miguel Lluch-Baixaulli y María Pilar Ferrer. Evangelización y teología en América (siglo XVI). Pamplona: Universidad de Navarra, pp. 627-642.

BRENDECKE, Arndt (2016). Imperio e información: funciones del saber en el dominio colonial español. Madrid: Iberoamericana-Vervuert.

Broggio, Paolo (2004). Evangelizzare il Mondo. Le missioni della Compagnia di Gesù tra Europa e America. Roma: Carocci.

Calvo, Thomas (2000). «El rey y sus Indias: ausencia, distancia y presencia (siglos XVI-XVIII)». En: Óscar Mazín Gómez (ed). México y el mundo hispánico. Zamora: Colmich, pp. 427-483.

CAntù, Francesca (2007). La Conquista spirituale. Studi sull'evangelizzazione del Nuovo Mondo. Roma: Viella.

Castañeda Delgado, Paulino y Juan Marchena Fernández (1992). La jerarquía de la Iglesia en Indias: El episcopado americano, 1500-1850. Madrid: Mapfre.

Dammert Bellido, José (1996). El clero diocesano en el Perú del siglo XVI. Lima: Instituto Bartolomé de las Casas - Rímac.

Durston, Alan (2007). Pastoral Quechua. The History of Christian Translation in Colonial Peru, 1550-1650. Notre Dame-Indiana: University of Notre Dame Press. 
Duve, Thomas y Heikki Pihlajamäki (eds.) (2015). New Horizons in Spanish Colonial Law. Contributions to transnational early modern legal history. Frankfurt am Main: Max Planck Institute for European Legal History.

García Añoveros, Jesús María (1990). La Monarquía y la Iglesia en América. La Corona y los pueblos americanos. Valencia: Asociación Francisco López de Gomara.

Gaudin, Guillaume (2013). Penser et gouverner le Nouveau Monde an XVIIIe siècle. L'empire de papier de Juan Diez de la Calle, commis du Conseil des Indes. París: L'Harmattan.

González Martínez, Nelson Fernando (2017). «Comunicarse a pesar de la distancia: La instalación de los Correos Mayores y los flujos de correspondencia en el mundo hispanoamericano (1501-1640)». Nuevo Mundo Mundos Nuevos. Publicación electrónica. Disponible en: $<$ https://journals.openedition.org/nuevomundo/71527>. Consulta: 20/0372021.

GruZINSKI, Serge (2006). «Mundialización, globalización y mestizajes en la Monarquía católica». En: Roger Chartier y Antonio Feros (dirs.). Europa, América y el mundo: tiempos históricos. Madrid: Fundación Rafael del Pino; Fundación Carolina; Marcial Pons, pp. 217-237.

GruZINSKI, Serge (2010). Las cuatro partes del mundo. Historia de una mundialización. México D. F.: Fondo de Cultura Económica.

Hernando SÁnchez, Carlos J. (1996). Las Indias en la Monarquía Católica: imagines e ideas políticas. Valladolid: Universidad de Valladolid.

Latasa Vassallo, M. Pilar (1997). Administración virreinal en el Perú: gobierno del marqués de Montesclaros (1607-1615). Madrid: Fundación Ramón Areces.

Latasa Vassallo, M. Pilar (2013). «Juan de Mendoza y Luna, Marqués de Montesclaros». Diccionario biográfico español. Vol. 34. Madrid: Real Academia de la Historia, pp. 595-598. 


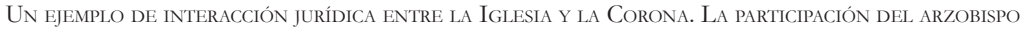

LeVILLIER, Roberto (1920). Santo Toribio Alfonso Mogrovejo, arzobispo de Los Reyes (1581-1606): organizador de la Iglesia en el virreinato del Perú. Madrid: Rivadeneyra.

LockHART, James y Stuart B. SChWARTZ (1992). América Latina en la edad moderna. Una historia de la América española y el Brasil coloniales. Madrid: Akal.

Lohmann Villena, Guillermo (1989). Seminario Conciliar de Santo Toribio. Cusco: Instituto Peruano de Historia Eclesiástica.

Maldavsky, Aliocha (2012). Vocaciones inciertas. Misión y misioneros en la provincia jesuita del Perú en los siglos XVI y XVII. Madrid: Consejo Superior de Investigaciones Científicas; Instituto Francés de Estudios Andinos.

Martínez Ferrer, Luis (2017). «Echi di Trento in America. L'approvazione romana del Concilio Provinciale di Lima (1582/83) riguardo al sistema delle scomuniche». En: Michela Catto y Adriano Prosperi (eds). Trent and Beyond. The Council, other powers, other cultures. Turnhout: Brepolis, pp. 443-460.

Masters, Adrian (2018). «A Thousand Invisible Architects: Vassals, the Petition and Response System, and the Creation of Spanish Imperial Caste Legislation». Hispanic American Historical Review, vol. 98, núm. 3, pp. 377-406.

Mazín Gómez, Osvaldo (2007). Gestores de la real justicia. Procuradores y agentes de las catedrales hispanas nuevas en la corte de Madrid. I. El ciclo de México: El ciclo de México, 1568-1640. México D. F.: El Colegio de México.

Mazín Gómez, Osvaldo (2010). «El clero secular y orden social en la Nueva España de los siglos XVI-XVII». En: Margarita Menegus, Francisco Morales y Osvaldo Mazín. Secularización de las doctrinas de indios en Nueva España: la pugna entre las dos iglesias. México D. F.: Bonilla Artigas Editores, pp 139-200. 
Merluzzi, Manfredi (2007). «Religion and state policies in the Age of Philip II: The 1568 Junta Magna of the Indies and the New Political Guidelines in Spanish American Colonies». En: J. Carvalho. Religion and Power in Europe. Conflict and Convergence. Pisa: Edizioni PLUS-Pisa University Press, pp. 183-201.

Merluzzi, Manfredi (2014). Gobernando los Andes. Francisco de Toledo virrey del Perú (1569-1581). Lima: Pontificia Universidad Católica del Perú.

Morales, Francisco (2010). «La iglesia de los frailes». En: Margarita Menegus, Francisco Morales y Osvaldo Mazín. Secularización de las doctrinas de indios en Nueva España: la pugna entre las dos iglesias. México D. F.: Bonilla Artigas Editores, pp. 13-76.

Moutin, Osvaldo Rodolfo (2016). Legislar en la América hispánica en la temprana edad moderna. Procesos y característica de la producción de los Decretos del Tercer Concilio Provincial Mexicano (1585). Frankfurt am Main: Max Planck Institute for European Legal History.

Navarro Bonilla, Diego (2006). «Del manejo del Imperio a la gestión doméstica: archivos y depósitos documentales en Madrid en torno a 1600». En: Cultura Escrita \& Sociedad, núm. 3, pp. 133-158.

Olmedo JimÉnez, Manuel (1990). «La instrucción de Jerónimo de Loaysa para doctrinar a los indios en los dos primeros concilios limenses (1545-1567)». En: José Barrado (ed.). Actas del II Congreso Internacional sobre los Dominicos y el Nuevo Mundo, Salamanca, 28 de marzo-1 abril de 1989. Salamanca: Editorial San Esteban, pp. 301-354.

Pérez Puente, Leticia (2009). El concierto imposible. Los concilios provinciales en la disputa por las parroquias indígenas (México, 1555-1647). Ciudad de México: Universidad Nacional Autónoma de México.

Pérez Puente, Leticia (2013). «La fundación del seminario conciliar y el fortalecimiento de la jurisdicción episcopal (Lima, 1564-1603)». En: Rodolfo Aguirre Salvador (ed.). Espacios de saber, espacios de poder. Iglesia, universidades y colegios en Hispanoamérica, siglos XVI-XIX. México: UNAM, pp. 85-116. 


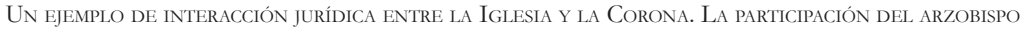

Pérez Puente, Leticia (2017). Los cimientos de la iglesia en la América española: los seminarios conciliares, siglo XVI. Ciudad de México: Universidad Nacional Autónoma de México.

Ramos Pérez, Demetrio (1999). «La Junta Magna de 1568: planificación de una época nueva». En: Demetrio Ramos Pérez (ed.). La formación de las sociedades iberoamericanas (1568-1700). Madrid: Espasa Calpe, pp. 39-61.

Recopilación de Leyes de los Reynos de las Indias mandadas imprimir y publicar por la Magestad católica del rey don Carlos II (1998 [1680]). Facsímile de la edición: por la viuda de d. Joaquín Ibarra (Madrid, 1791). 3 volúmenes. Madrid: Centro de Estudios político y Constitucionales.

Rodríguez Valencia, Vicente (1958). Santo Toribio de Mogrovejo, organizador y apóstol de Sur-América. 2 volúmenes. Madrid: Instituto Santo Toribio de Mogrovejo; CSIC.

Sánchez Bella, Ismael (1991). Derecho Indiano: estudios. Volumen 2: Fuentes, literatura jurídica, derecho público. Pamplona: Ediciones Universidad de Navarra.

Sánchez Belda, Ismael (1995). Nuevos estudios de Historia del Derecho Indiano. Pamplona: Eunsa.

Sánchez Belda, Ismael, Alberto De La Hera y Carlos Díaz Rementería (1992). Historia del Derecho Indiano. Madrid: Mapfre.

Sanfilippo, Matteo y Giovanni Pizzorusso (2004). «L'America iberica e Roma fra Cinque e Seicento: notizie, documenti, informatori». En: Matteo Sanfilippo, Alexander Koller y Giovanni Pizzorusso (eds.). Gli archivi della Santa Sede e il mondo asburgico nella prima età moderna. Viterbo: Sette Città, pp. 73-118.

SaranYana, Josep Ignasi (1999). «El III Concilio limense (1582-1583)». En: Josep Ignasi Saranyana (dir.). Teología en América Latina: desde los orígenes a la Guerra de Sucesión (1493-1715). Madrid; Frankfurt am Main: Iberoamericana/Vervuet, pp. 141-173. 
Sellers-García, Sylvia (2014). Distance and documents at the Spanish Empire's Periphery. Stanford (California): Stanford University Press.

Solano F. DE (1991). «La delegación del poder en América». En: M. Ganci y R. Romano (eds.). Governare il mondo. L'Impero spagnolo dal XV al XIX secolo. Palermo: Società Siciliana per la Storia Patria, pp. 51-66.

Solórzano Pereira, Juan de (2001 [1629]). De Indiarum iure. (Liber I: De inquisitione indiarum). Edición y traducción de Carlos Baciero, L. Baciero, Ana María Barrero, Jesús María García Añoveros y José María Soto Rábanos. Madrid: Consejo Superior de Investigaciones Científicas.

Tau AnzoÁtegui, Víctor (1992). Casuismo y Sistema: indagación histórica sobre el espiritu del Derecho Indiano. Buenos Aires: Instituto de Investigaciones de Historia del Derecho.

Tau Anzoátegui, Víctor (1997). Nuevos horizontes en el estudio histórico del Derecho Indiano. Buenos Aires: Instituto de investigaciones de Historia del Derecho.

Tau Anzoátegui, Víctor (2016). El Jurista en el Nuevo Mundo. Pensamiento. Doctrina. Mentalidad. Frankfurt am Main: Max Planck Institute for European Legal History.

Tercer ConCilio Limense (1583-1591). Edición bilingüe de los decretos (2017 [1583]). Edición por Luis Martínez Ferrer y José Luis Gutiérrez. Lima: Facultad de Teología Pontificia y Civil.

TERrÁneo, Sebastián (2020). Introducción al derecho y a las instituciones eclesiásticas indianas. Buenos Aires: Pontificia Universidad Católica Argentina.

Tineo, Primitivo (1990). Los concilios limenses en la evangelización latinoamericana. Pamplona: EUNSA.

Traslosheros, Jorge E. (2014). Historia judicial eclesiástica de la Nueva España; materia, método y razones. México D. F.: Editorial Porrúa México. 
Un EJEMPLO DE INTERACCIÓN JURÍDICA ENTRE LA IgLESIA Y LA CORONA. LA PARTICIPACIÓN DEL ARZOBispo

Toribio Mogrovejo en el proceso de toma de decisión de la Monarquía Hispánica (1580-1606)

Valpuesta Abajo, Nazario (2008). El clero secular en la América Hispana del siglo XVI. Madrid: BAC.

Vargas Ugarte, Rubén (1951). Concilios Limenses (1551-1572). Lima: Ràvago e hijos.

Vargas Ugarte, Rubén (1963-1965). Historia de la Compañia de Jesús en el Perú. Burgos: Imprenta de Aldecoa.

Fecha de recepción: 12 de enero de 2021. Fecha de evaluación: 18 de febrero de 2021.

Fecha de aceptación: 6 de abril de 2021.

Fecha de publicación: 1 de noviembre de 2021.

(C) (1) $(9)$ 